
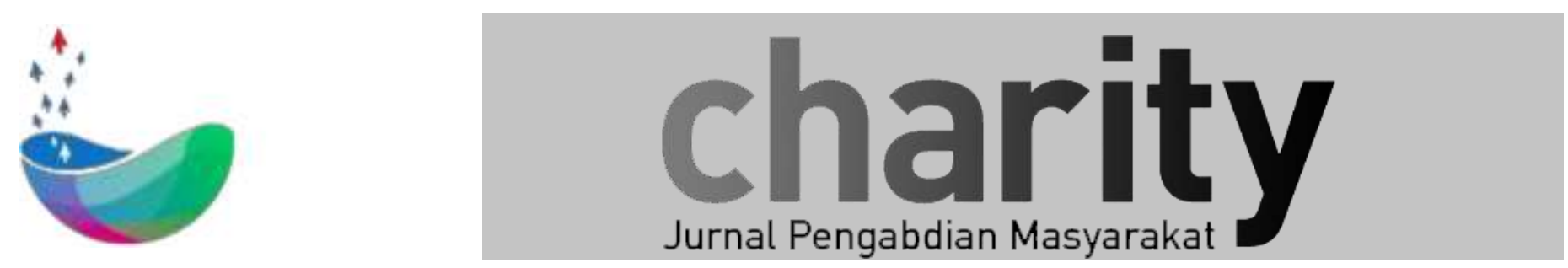

\title{
Desain Kemasan untuk Mendukung Pemasaran Produk Olahan Pangan Kelompok Wanita Tani Kreatif Permata
}

\author{
Sheila Andita Putri ${ }^{1}$, Teuku Zulkarnain Muttaqien ${ }^{2}$, Asep Sufyan Muhakik Atamtajani ${ }^{3}$. \\ ${ }^{1}$ Desain Produk, Fakultas Industri Kreatif, Telkom University \\ ${ }^{2}$ Desain Produk, Fakultas Industri Kreatif, TelkomUniversity \\ ${ }^{3}$ Desain Produk, Fakultas Industri Kreatif, TelkomUniversity \\ chesheila@telkomuniversity.ac.id, zulkarnain.muttaqien@gmail.com, krackers@telkomuniversity.ac.id
}

\section{INFO ARTIKEL}

Diterima 22 Juli 2019

Direvisi 29 Juli 2019

Disetujui 30 Agustus 2019

Tersedia Online 09

September 2019

\begin{abstract}
ABSTRAK
Kelompok Wanita Tani (KWT) Kreatif Permata yang berlokasi di Bojongsoang, Bandung hingga kini aktif menjalankan kegiatan budidaya tanaman sayuran dan tambak ikan secara organik. Produk yang dihasilkan umunya berupa hasil panen segar. Sebagai bagian dari proses diversifikasi produk, KWT Kreatif Permata bersama Telkom University mengembangkan produk olahan pangan berbahan dasar sayuran dan ikan segar hasil panen dari budidaya yang dilakukan anggota KWT. Produk olahan yang saat ini berhasil dikembangkan adalah produk baso ikan yang terbuat dari hasil budidaya ikan KWT dan produk berbahan dasar sayuran segar seperti mie kering dan roti manis siap saji. Produk olahan ini akan dipasarkan kepada konsumen diluar lingkungan KWT. Untuk mendukung kegiatan pemasaran, produk perlu dilengkapi dengan kemasan yang didesain khusus. Desain kemasan yang akan dibuat bertujuan untuk menarik calon konsumen sekaligus menampilkan informasi menganai produk dan KWT Kreatif Permata.
\end{abstract}

Keyword: desain kemasan, olahan pangan, KWT, pemasaran produk

\author{
Korespondensi: \\ Direktorat Penelitian dan Pengabdian Masyarakat, Universitas Telkom \\ Jl. Telekomunikasi No. 1, Terusan Buah Batu, Bandung, 40257 \\ Indonesia \\ E-mail : charity@telkomuniversity.ac.id \\ ORCID ID: 0000-0001-6951-6337 \\ Penulis Pertama: Sheila Andita Putri \\ https://doi.org/10.25124/charity.v2i1.2143
}

Paper_reg_number 2143 @ T The Authors. Published by Directorate of Research and Community Service, Telkom University.

This is an open access article under the CC BY-NC 4.0 license (https://creativecommons.org/licenses/CC BY-NC 4.0) 


\section{Pendahuluan}

Kelompok wanita tani (KWT) Kreatif Permata Desa Lengkong merupakan salah satu dari dua KWT yang berada di Kecamatan Bojongsoang. Kegiatan KWT Kreatif Permata cukup beragam, mulai dari budidaya sayuran hingga beternak ikan. Kagiatan budidaya sayuran dimulai dari pembukaan lahan, pembangunan media tanam, pembibitan, penanaman, hingga panen. Untuk peternakan ikan dilakukan dengan kolam akuatik yang dilengkapi dengan filter air. Seluruh proses budidaya sayuran dan tambak ikan dilakukan secara organic sehingga dapat memberikan manfaat kesehatan yang lebih baik daripada produk sejenis yang dibudidayakan secara kimia.

Hasil panen sayuran dan ikan KWT Kreatif Permata biasa dijual dalam keadaan segar. Selain dijual segar, hasil panen juga dioleh menjadi berbagai produk olahan pangan yang siap dikonsumsi. Produk olahan yang saat ini tengah dikembangkan bersama Telkom University adalah Mie Kering Sayuran, Baso Ikan, dan Roti Manis Sayuran. Sebagai produk baru, KWT Kreatif Permata perlu menampilkan produknya dengan cara yang menarik untuk menarik konsumen dan mendukung pemasaran produk. Untuk meningkatkan nilai jual produk, hasil olahan pangan KWT Kreatif Permata ini perlu dikemas dengan kemasan yang didesain khusus. Desain kemasan ini dibuat selain untuk menjaga keamanan bentuk produk saat dijual juga untuk menampilkan informasi produk dan KWT Kreatif Permata sebagai produsen. 


\section{Permasalahan dan Solusi yang Ditawarkan}

\subsection{Permasalahan}

Sejauh ini hasil produksi KWT Kreatif Permata yang rutin dipasarkan adalah hasil panen ikan dan aneka sayuran. Minat konsumen terhadap produk hasil budidaya KWT Kreatif Purnama cukup tinggi, apalagi kesadaran mengenai manfaat produk segar organik terhadap gaya hidup sehat telah dikenal luas oleh masyarakat. Namun sayangnya hasil panen ini belum dapat dipasarkan secara kontinu kepada konsumen karena jadwal panen tanaman sayuran dan ikan KWT Kreatif Permata belum teratur. Inkonsistensi waktu panen ini ada akhirnya menyebabkan produk segar KWT Kreatif Permata belum dapat dipasarkan langsung ke pasar yang lebih luas. Untuk menghindari rusaknya hasil panen, biasanya hasil Panen dijual kepada masyarakat di sekitar lingkungan KWT ataupun dikonsumsi sendiri oleh anggota KWT.

Untuk memaksimalkan hasil panen KWT Kreatif Permata, dilakukan pengembangan produk pangan olahan dengan bahan baku dasar sayuran dan ikan yang dihasilkan oleh para anggota. Pengambangan produk olahan ini merupakan hasil kerjasama Telkom University dan KWT Kreatif Permata, mulai dari pengembangan resep, teknik pengolahan, hingga proses pengemasan. Produk pangan ini memiliki daya simpan yang lebih panjang daripada produk sayuran segar sehingga diharapkan dapat diproduksi dan dipasarkan secara rutin ke pasar yang lebih luas. Dengan promosi yang tepat, produk pangan olahan ini diharapkan mampu menarik konsumen diluar lingkungan KWT Kreatif Permata.

\subsection{Solusi yang ditawarkan}

Produk pangan olahan ini perlu dikemas untuk menjaga keamanan produk saat didistribusikan. Namun selain alasan tersebut, kemasan juga harus dapat mendukung promosi KWT Kreatif Permata dan menarik minat konsumen. Untuk mampu menarik minat konsumen, perlu dibuat desain kemasan yang unik sekaligus informative dalam menyampaikan informasi produk dan KWT Kreatif Permata sebagai produsen.

Produk yang akan dikemas adalah produk hasil pengembangan produk pangan olahan dengan bahan baku dasar sayuran dan ikan yang dihasilkan oleh para anggota. Ragam produk yang dimaksud adalah Baso Ikan, Mie Kering Sayuran, dan Roti Manis Sayuran.

Hasil desain kemasan akan digunakan untuk mengemas produk dengan aman dan menarik. Tujuannya adalah untuk meningkatkan nilai produk saat dipasarkan ke calon konsumen sekaligus menginformasikan keunggulan produk KWT Kreatif Permata kepada masyarakat. 


\section{Metode Pelaksanaan}

Proses desain dimulai dari menganalisa karakter produk yang akan dikemas, dalam hal ini produk olahan pangan KWT Kreatif Permata. Produk olahan yang akan dikemas adalah Baso Ikan, Mie Kering Sayuran, dan Roti Manis Sayuran. Analisa mencakup karakter produk, bobot, cara penyimpanan, dan metode pengolahan produk hingga dapat dinikmati oleh konsumen.

Setelah proses analisa dilakukan, langkah selanjutnya adalah menentukan dimensi kemasan dan material yang digunakan. Dimensi kemasan disesuaikan dengan volume produk per sajian. Pemilihan material didasarkan pada karakter produk, ketahanan material, dan efektifitas produksi.

Pemilihan bentuk dan material kemasan kemudian dilengkapi dengan desain perwajahan kemasan. Desain perwajahan kemasan dimuali dengan merancang merek produk yang mewakili KWT Kreatif Permata. Desain merek produk ini mencakup identitas visual merek yang akan ditampilkan pada kemasan. Visualisasi kemasan kemudian didukung dengan perancangan elemen estetik kemasan yang mendukung identitas merek dan karakter produk. Visualisasi ini dirancang berdasarkan identitas merek KWT Kreatif Permata, jenis produk, dan selera target konsumen. Hasil perancangan kemudian diproduksi dan langsung digunakan oleh anggota KWT Kreatif Permata untuk mengemas produk olahan pangan yang akan dipasarkan. 


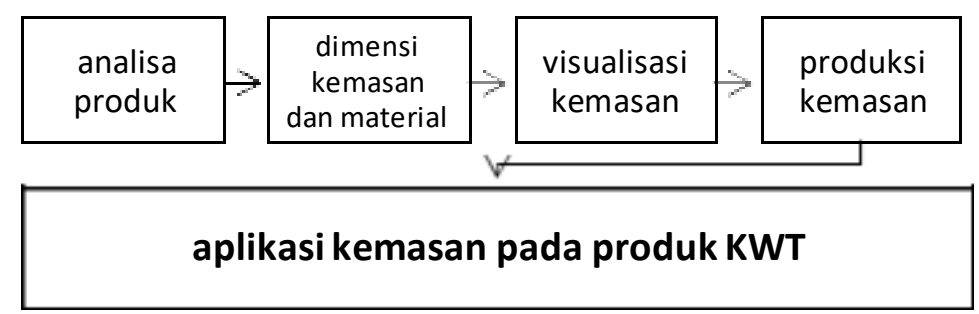

Gambar 3.1 Diagram Metode Perancangan.

\section{Hasil dan Pembahasan}

\subsection{Analisa produk}

Produk olahan pangan KWT Kreatif Permata yang saat ini akan dipasarkan adalah produk Baso Ikan, Mie Kering Sayuran, dan Roti Manis Sayuran. Produk baso ikan dibuat dari hasil tambak ikan yang dikelola oleh KWT. Ikan diternakkan secara organic sehingga daging ikan yang dihasilkan lebih sehat tanpa tambahan zat kimia dan ukuran ikan lebih besar. Baso ikan KWT Permata dibuat secara manual oleh para anggota. Komposisi baso ikan terdiri atas daging ikan yang telah dihaluskan, bumbu penyedap, dan tepung yang berfungsi untuk membentuk struktur baso menjadi lebih kenyal dan padat. Bahan- bahan ini dicampurkan dan dibentuk menjadi bola- bola kecil dengan tangan. Adonan yang telah dibentuk kemudian direbus hingga mengapung dan siap dikonsumsi. Warna baso ikan yang dihasilkan putih bersih sesuai warna daging ikan segar sebelum diolah. Baso yang sudah direbus kemudian ditakar menjadi beberapa porsi. Tiap takaran porsi baso ikan memiliki berat 500 gram. Baso yang sudah ditakar kemudian disimpan dalam keadaan beku setelah dibungkus plastik.

Produk olahan pangan KWT Kreatif Permata lainnya berbahan dasar hasil panen sayuran segar yang ditanam oleh anggota KWT. Salah satu produk olahan tersebut aadalah mie kering sayuran. Produk mie kering ini dibuat dari daun sayuran kale yang dihaluskan sehingga memberikan warna hijau yang khas pada produk mie kering ini. Kale yang dihaluskan ini kemudian dicampurkan dengan bahan- bahan lain seperti tepung, telur, dan penyedap hingga membentuk adonan. Adonan yang terbentuk kemudian digiling dan dimasukkan ke alat pencetak mie hingga terbentuk helaian mie yang halus. Hasil cetakan ditaburi tepung Untuk mencegah helaian mie saling menempel. Mie dapat langsung diolah untuk segera dikonsumsi dengan cara direbus, namun untuk penyimpanan jangka panjang diperlukan proses pengeringan pada adonan mie yang sudah digiling. Mie yang sudah dikeringkan siap dipasarkan dengan bobot 100 gram per porsi 
Produk terakhir yang juga berbahan dasar sayuran adalah roti manis sayuran. Produk siap makan (ready- to- eat) ini mengandung daun sayuran kale yang dihaluskan sebagai pewarna alami sekaligus menambahkan nutrisi pada produk. Proses pembuatannya dimulai dengan mencampurkan Kale yang telah dihaluskan kedalam adonan roti. Adonan roti manis ini sendiri terdiri dari tepung, telur, gula, ragi, dan mentega. Penambahan Kale membuat adonan roti menjadi berwarna kehijauan sebelum adonan diuleni hingga kalis dan dibiarkan hingga mengembang. Setelah adonan mengembang dan volumenya bertambah, adonan dimasukkan ke dalam cetakan roti berbentuk kubus dan dipanggang di oven hingga matang. Roti yang telah dipanggang siap dikemas untuk dipasarkan.

\subsection{Dimensi dan material kemasan}

Dimensi kemasan menyesuaikan volume produk per porsi. Untuk produk baso ikan, volume produk adalah 500 gram per porsi. Untuk mengemas produk bakso yang dibungkus plastic dan divacuum, bentuk kemasan yang dipilih adalah Pillow- box. Bentuk kemasan pillow-box memudahkan proses pengemasan sekaligus memudahkan produk untuk keluar saat akan digunakan. Dilihat dari efisiensi dan harga kemasan, bentuk pillowbox juga lebih ekonomis daripada bentuk kotak biasa. Dimensi kemasan baso ikan memiliki panjang 21 centimeter, lebar 16 centimeter, dan lebar bukaan (tebal maksimal) kemasan 5 centimeter. Material yang dipilih adalah artpaper food-grade.

Untuk produk mie kering, bobot per porsi adalah 100 gram. Umumnya kemasan mie kering dengan volume yang sama dikemas menggunakan plastik, namun untuk menampilkan eksklusifitas produk mie kering KWT Kreatif Permata maka material kemasan yang dipilih adalah material yang lebih kokoh dan kaku seperti artpaper foodgrade. Bentuk kemasan yang dipilih untuk mengemas produk mie adalah kotak dengan dimensi panjang 14 centimeter dan lebar 11 centimeter dengan ketebalan 5 centimeter. Bentuk kemasan ini dimaksudkan agar produk mie kering tidak mudah hancur saat ditumpuk dengan produk sejenis ketika didistribusikan.

Produk terakhir yang akan dikemas adalah produk roti manis sayuran. Untuk produk roti manis ini, kemasan yang akan dibuat diperuntukkan untuk mengemas roti satuan. Setiap roti berbentuk kubus, berukuran 7 hingga 8,5 centimeter. Roti akan dikemas dalam kotak berbentuk kubus dengan dimensi panjang 9 centimeter. Bentuk ini dipilih untuk menonjolkan bentuk roti. Material yang dipilih adalah artpaper food-grade.

\subsection{Perwajahan kemasan}

Desain perwajahan kemasan dimulai dari pembuatan identitas KWT Kreatif Permata. Identitas yang akan dibuat mencap penentuan nama merek dan logo. Nama merek yang akan digunakan pada setiap produk KWT Kreatif Permata adalah 'Creative Garden'. Kata 'Creative' pada merek ini diambil dari KWT 'Kreatif' Permata, dan kata 'Garden' digunakan untuk menunjukkan lingkup KWT yang berorientasi pada pertanian. Merek 'Creative Garden' kemudian divisualisasikan dalam bentuk logo yang mengadopsi bentuk dan warna dari tanaman. 


\section{Creative}

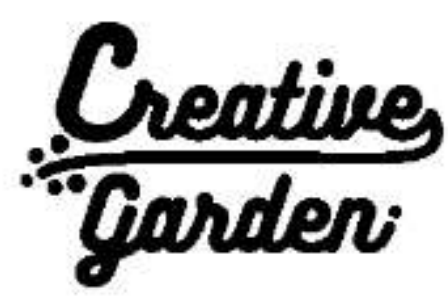

Gambar 4.1 Logo dan Merek produk KWT Kreatif Permata

Secara umum, tampak depan kemasan menampilkan logo/ merek produk untuk memudahkan identifikasi produk oleh konsumen. Selain logo/ merek, tampak depan juga menampilkan informasi jenis/ varian produk dan bobot produk. tampak belakang kemasan menampilkan informasi produk seperti keunggulan produk, komposisi, dan metode penyimpanan /saran penyajian. Informasi produsen dan tanggal kadaluarsa ditampilkan pada sisi kiri dan kanan kemasan.

Perwajahan dari kemasan baso ikan menampilkan ikon yang menyerupai kepala ikan pada tampak depan. Warna yang dipilih adalah warna kontras, dimana kepala ikan diwarnai dengan warna kuning dan warna biru toska digunakan sebagai latar belakang.
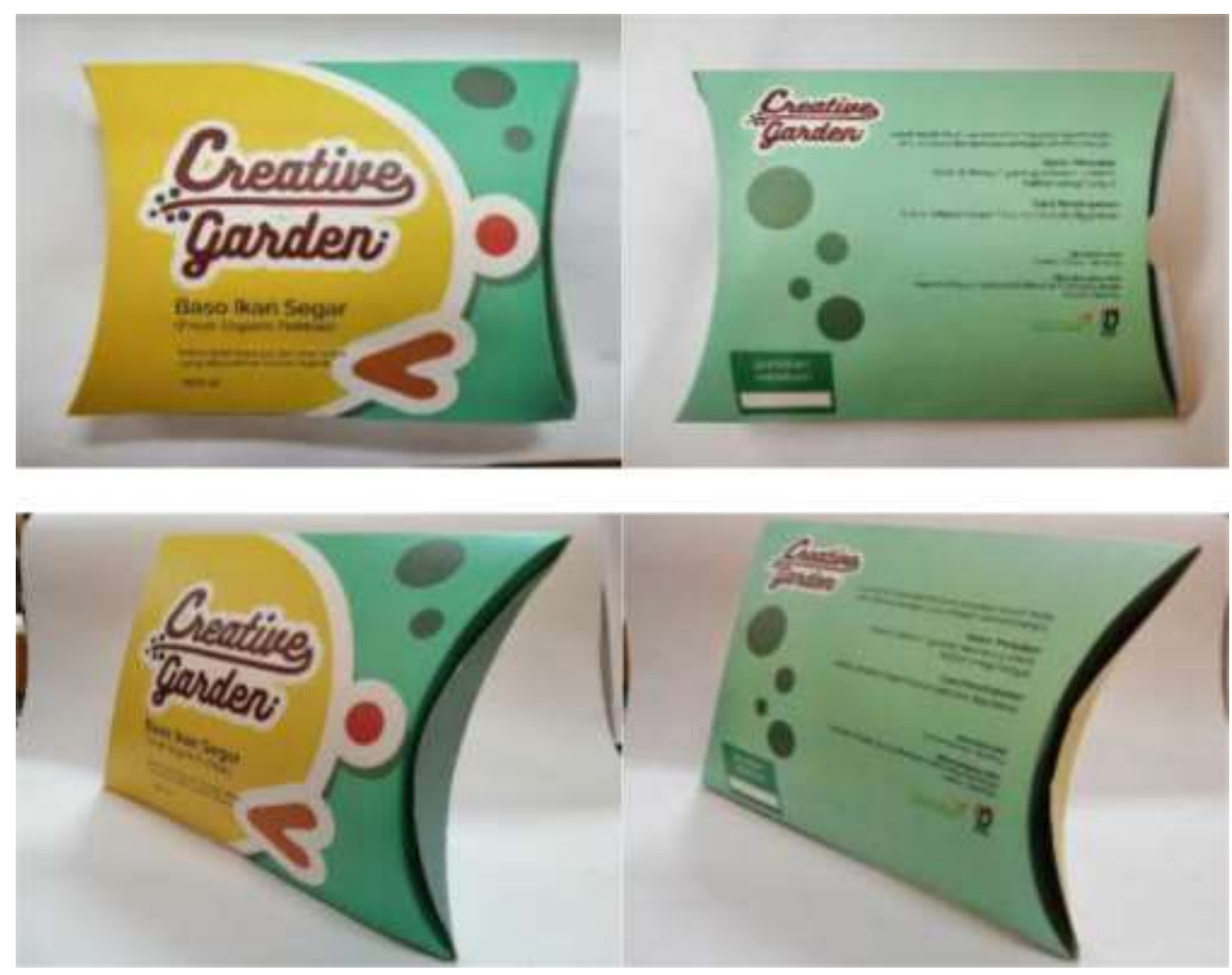

Gambar 4.2 Hasil Desain Kemasan Produk Baso Ikan KWT Kreatif Permata 
Untuk kemasan mie kering sayuran, Pada tampak depan ditambahkan ilustrasi mie berwarna hijau untuk memberikan informasi mengenai tampilan produk. Kemasan mie kering sayuran didominasi oleh warna kuning. Warna ini dipilih untuk menonjolkan ilustrasi mie yang berwarna hijau pada tampak depan kemasan. Warna kuning ini juga mendominasi tampak belakang kemasan. Warna tulisan yang dipilih adalah hitam agar mudah dibaca.

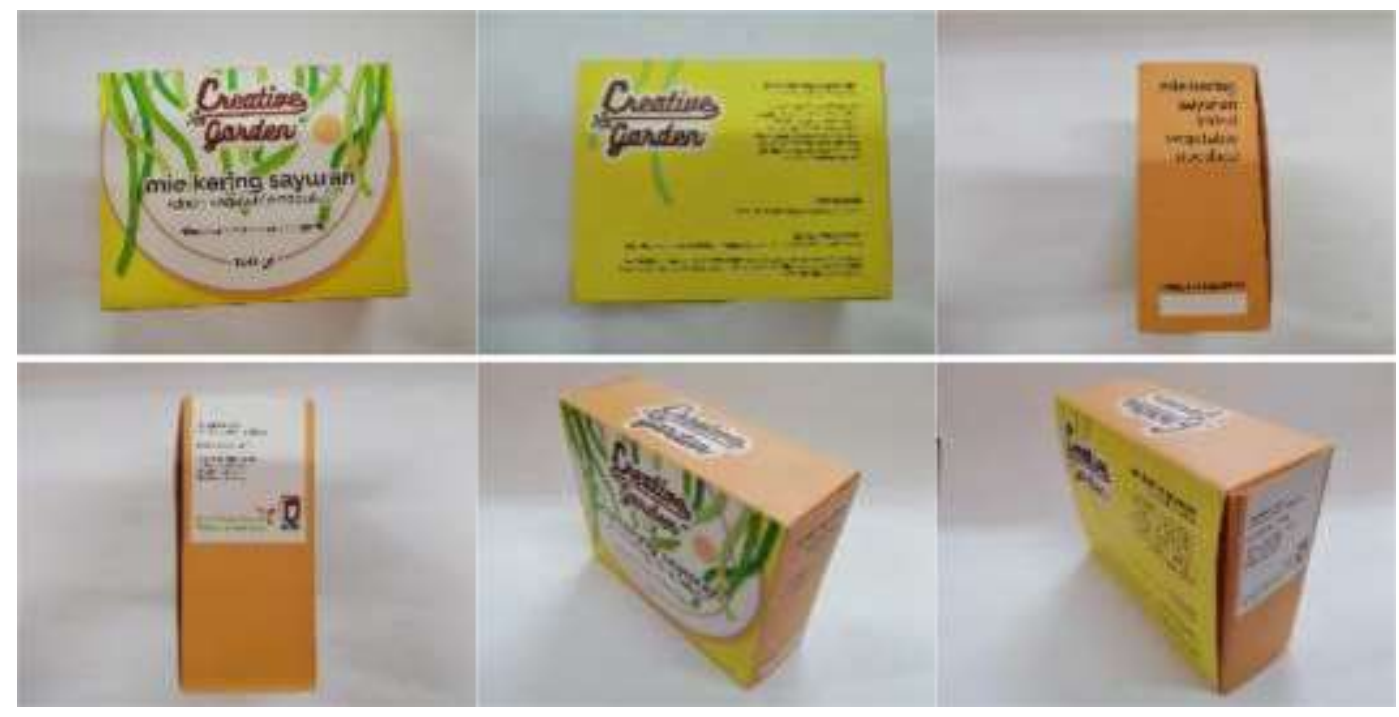

Gambar 4.3 Hasil Desain Kemasan Produk Mie Kering Sayuran KWT Kreatif Permata

Produk terakhir yang perlu didesain kemasannya adalah roti manis sayuran. Bentuk kemasan menyesuaikan bentuk roti yang berupa kubus. Kemasan didominasi warna merah dengan motif polkadot putih dengan kombinasi warna cokelat. Kombinasi warna ini dipilih untuk menampilkan kesan ceria dan menarik perhatian.

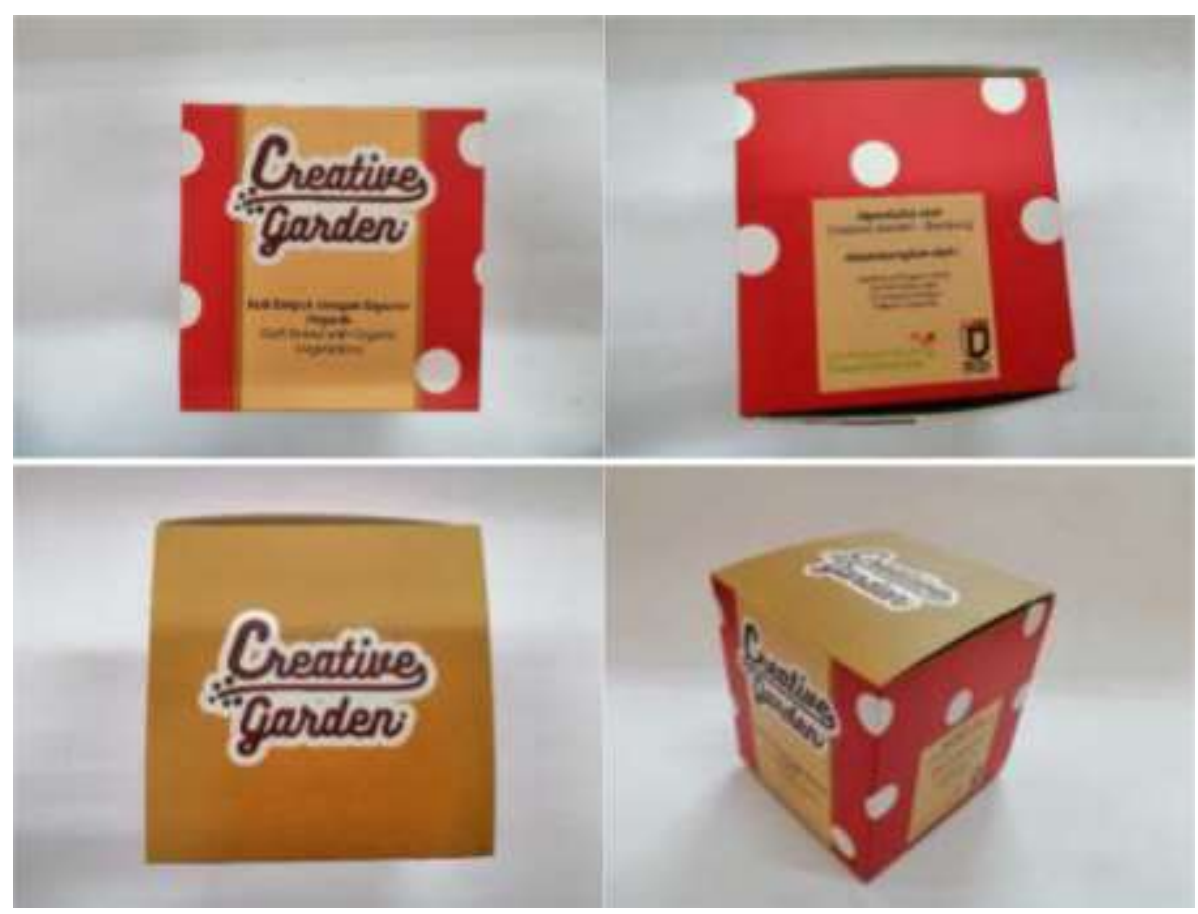

Gambar 4.4 Hasil Desain Kemasan Produk Roti Manis Sayuran KWT Kreatif Permata 
Hasil desain kemasan kemudian diproduksi dan digunakan untuk mengemas produk olahan pangan KWT Permata. Proses pengemasan dilakukan oleh para anggota KWT kreatif Permata. Produk yang telah dikemas kemudian siap dijual kepada konsumen. Desain kemasan yang dibuat diharapkan dapat meningkatkan nilai jual produk dan mendukung pemasaran produk di pasar yang lebih luas.

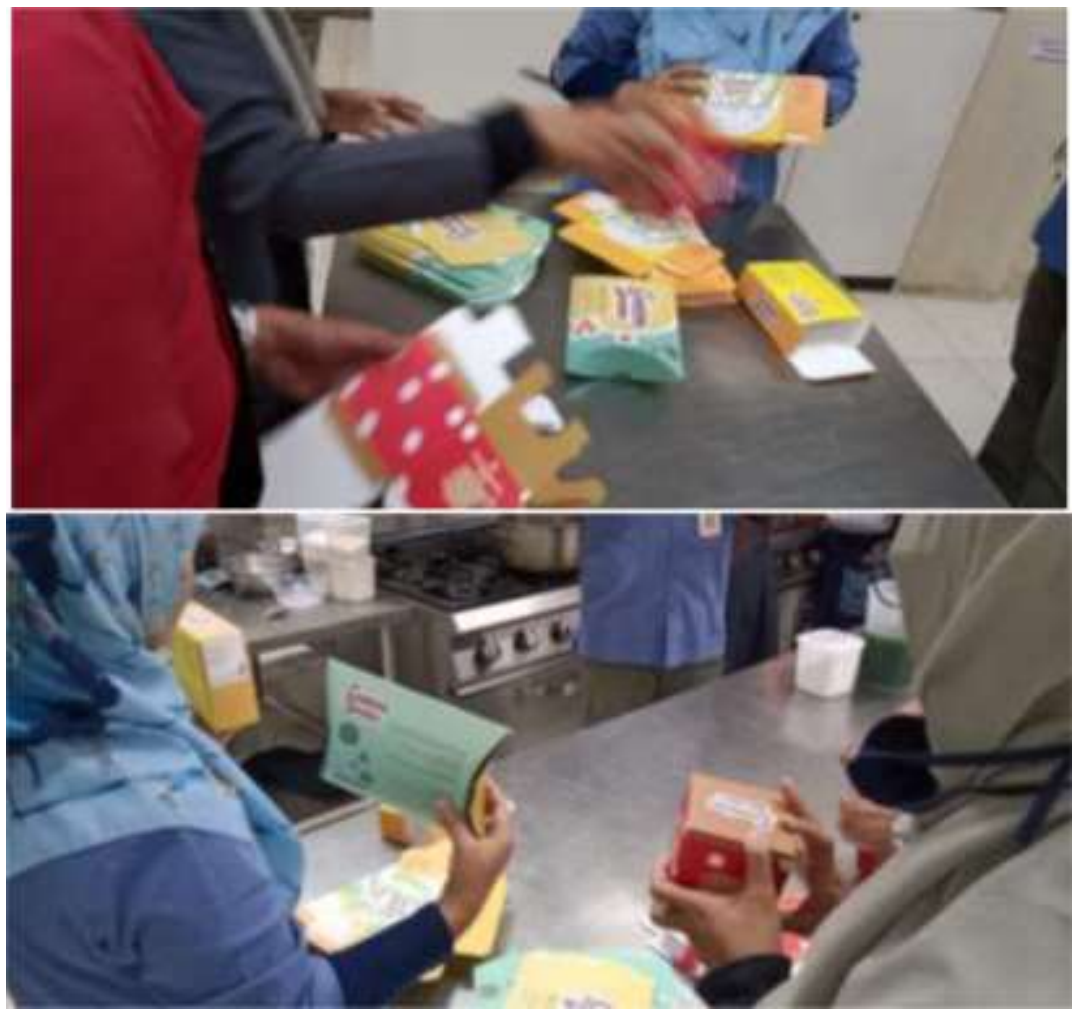

Gambar 4.5 Pengemasan Produk KWT Kreatif Permata oleh anggota KWT

\section{Kesimpulan}

Produk KWT kreatif permata memiliki keunggulan berupa hasil budidaya sayuran dan ikan yang dilakukan secara organic sehingga memiliki manfaat kesehatan yang lebih baik. Hasil panen sayuran dan ikan kemudian diolah menjadi produk olahan pangan yang dapat disimpan dalam jangka waktu yang lebih panjang sehingga memungkinkan untuk dipasarkan ke konsumen yang lebih luas. Untuk menarik konsumen, produk perlu didukung dengan desain kemasan yang selain mampu melindungi produk didalamnya, memberikan informasi mengenai produk dan KWT Kreatif Permata sebagai konsumen, serta juga mampu memberikan nilai estetis pada produk. hasil desain kemasan yang dibuat dapat diaplikasikan untuk mendukung pemasaran produk.

\section{DAFTAR PUSTAKA}

[1] Pikiran Rakyat, " Potensial Kembangkan Pertanian, Kelompok Wanita Tani Belum Diberdayakan," 2017. [Online]. Available: (http://www.pikiranrakyat.com/nasional/2017/09/29/potensial-kembangkan- 
pertanian-kelompok-wanita-tani-belum-diberdayakan-410513). [Diakses 6 Maret 2019]. 